\title{
Brow Presentation
}

National Cancer Institute

\section{Source}

National Cancer Institute. Brow Presentation. NCI Thesaurus. Code C113495.

A fetal presentation during delivery in which the brow of the fetus is first to descend into the birth canal. 